\title{
THE ADVANTAGES OF ANTIBIOTIC PROPHYLAXIS IN NEUROSURGERY
}

\author{
Predrag Milošević ${ }^{1}$, Boban Jelenković1, Nebojša Miljković2, Goran Ivanov², \\ Miroslav Popović ${ }^{2}$
}

\begin{abstract}
Prophylactic use of antibiotics in neurosurgery means the use of antibiotics in order to prevent infections of wounds and internal operative structures.

The research was conducted on 44 patients with L4-L5 and L5-S1 disc herniation operated at the Clinic of Neurosurgery in Niš during 2018. In 26 patients, antibiotic prophylaxis was used. In the remaining 18 patients, antibiotic prophylaxis was not applied and they were grouped into a control group. The average duration of the operation was 50 minutes. The antibiotic was used in a single dose first generation Cephalosporin, Cefazolin $1 \mathrm{~g}$ IV for patients with body weight less than $80 \mathrm{~kg}$ and $2 \mathrm{~g}$ for patients with body weight more than $80 \mathrm{~kg}$.

We observed the occurrence of wound infections and internal operational structures, the occurrence of unwanted effects and financial aspects.

The goal of the work was to demonstrate that antibiotic prophylaxis is more favorable due to shorter time use of antibiotics, less side effects and overall financial benefit comparing to continuous antibiotic therapy.
\end{abstract}

Acta Medica Medianae 2020;59(2):14-19.

Key words: antibiotic prophylaxis, neurosurgery, wound infections

${ }^{1}$ Clinical Center Niš, Clinic of Neurosurgery, Niš, Serbia

${ }^{2}$ Clinical Center Niš, Clinic of Anesthesia, Niš, Serbia

Contact: Predrag Milošević

10 Jovan Skerlić St., 18000 Niš, Serbia

E-mail: pedja@doctor.com

\section{Introduction}

Infection means the penetration of microorganisms into the body, with all the consequences of their mutual reactions, with both actors trying to maintain it.

An important condition for the emergence of infection is that a certain number of pathogenic or conditionally pathogenic microorganisms come into contact with sensitive tissue and multiplies there.

Surgical infections always penetrate the tissue through the front door in which local defense inflammatory reaction of the tissue has primary role, and then it is quickly associated with the general reaction of the organism. Significant factors for the development of a surgical infection are: the amount of inoculated microorganisms, i.e., their reproduction and excretion properties, and the resistance of the patient's organism to infection, which has been reduced in people with atherosclerotic blood vessels and chronic patients. Hospital infections are one of the leading causes of increased morbidity and mortality of hospitalized patients (1-5), malnutrition patients, hypoproteinemic and anemic, as well as those with malignant diseases.

The causative agents of the bacterial infection in operated neurosurgical patients usually come from the immediate environment, such as the patient's bacterial flora or in the presence of aerobic bacteria in the operating room during surgical work and those represent a high risk for the development of the infection. In neurosurgical patients, the infection occurs in $3-4 \%$ of cases $(6,7)$.

Antibiotic prophylaxis involves the use of antibiotics before the onset of infection, to prevent contamination of the operative wound by bacteria that represent a normal skin flora such as $S$. aureus, $S$. epidermidis, $P$. acnes, or contamination of pathogenic bacteria from the patient's environment during and after the procedure.

The use of antibiotics prophylactically aims to achieve sufficient concentration of bactericides in the tissue during intervention and for the first 3-4 hours postoperatively. Another way of using antibiotics prophylactically is to use them a few days before and after surgery and it is not justified because it represents a realistic modality for spreading resistance in a hospital setting (8).

The most common causes of infection at the Clinic of Neurosurgery in Niš are: 
- S. epidermidis

- S. aureus

- P. aeruginosa

- Citrobacter

- P. vulgaris

- P. mirabilis

- Acinetobacter

Prophylaxis has been used in neurosurgery since 1925, before the age of antibiotics, when the antiseptic Hexamine was used. Harvey Cushing, a pioneer of neurosurgery, had a rate of postoperative infections of $1 \%$ using only water and soap. From Cushing's era, all neurosurgeons use aseptic techniques in all types of operations (9).

\section{Materials and methods}

The research was carried out at the Clinic of Neurosurgery KC Niš.
During this study, we examined the effects of antibiotic prophylaxis in patients treated for lumbar disc hernias. The study was performed in 44 patients with their consent. In 26 patients, antibiotic prophylaxis was used. For the remaining 18 patients antibiotic prophylaxis was not used and they were assigned to the control group. We followed the movement of laboratory parameters of inflammation: CRP, sedimentation and leukocytes before and after surgery in 44 patients.

The average duration of the surgery was 50 minutes. Antibiotic was used in a single dose first generation Cephalosporin - Cefazolin $1 \mathrm{~g}$ IV for patients with body weight less than $80 \mathrm{~kg}$ and $2 \mathrm{~g}$ for patients with body weight more than $80 \mathrm{~kg}$.

\section{Results}

There was no statistically significant difference in wound infection depending on the use of antibiotic therapy $\left(\chi^{2}=1.076 ; p=0.583\right)$ (Table 1$)$.

Table 1. Infections of wounds and deeper structures when antibiotic prophylaxis used

\begin{tabular}{||c||ccc|ccc||}
\hline Infections & $\begin{array}{c}\text { Wound } \\
\text { infections }\end{array}$ & $\begin{array}{c}\text { Infections } \\
\text { of deeper } \\
\text { structures }\end{array}$ & No infections & Total & $\chi^{\mathbf{2}}$ & p \\
\hline \hline $\begin{array}{c}\text { Antibiotic } \\
\text { prophylaxis } \\
\text { Continuous } \\
\text { antibiotic } \\
\text { therapy }\end{array}$ & $1(33.3 \%)$ & $0(0.0 \%)$ & $25(62.5 \%)$ & $26(59.1 \%)$ & & \\
\hline \hline Total & $3(67.3 \%)$ & $1(100.0 \%)$ & $15(37.5 \%)$ & $18(40.9 \%)$ & $\mathbf{1 . 0 7 6}$ & $\mathbf{0 . 5 8 3}$ \\
\hline
\end{tabular}

A statistically significant difference in the distribution of side effects was determined depending on the use of antibiotic therapy $\left(\chi^{2}=15.634 ; \mathrm{p}=\right.$ 0.001 ). A significantly higher number of patients who had antibiotic prophylaxis were without side effects, while patients with continuous antibiotic therapy more often had nausea and vomiting, diarrhea and stomach pain (Table 2).

Table 2. Frequency of side effects

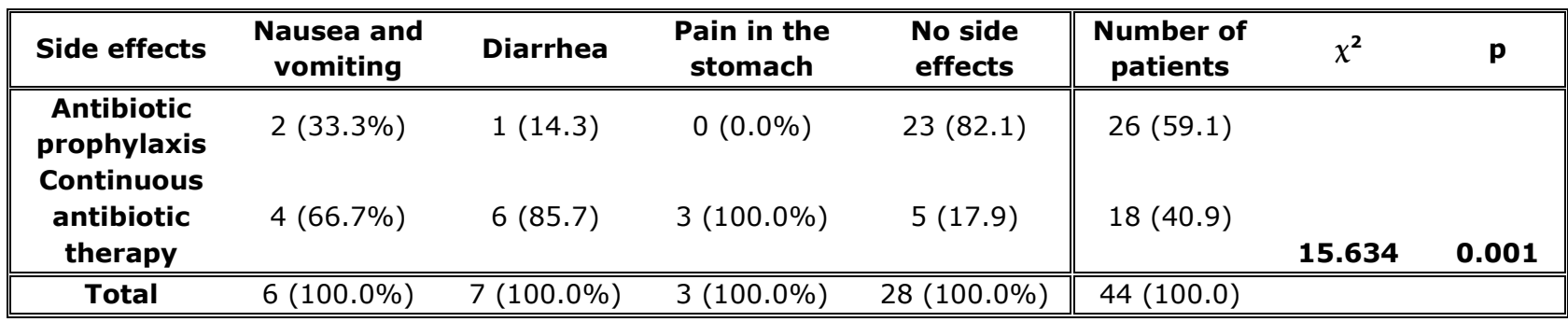

A statistically significant difference in funding was found, depending on the use of antibiotic therapy $\left(\chi^{2}=14.123 ; p<0.001\right)$. Patients for whom funds of up to RSD 2000 were spent for 
antibiotic therapy were more likely to have antibiotic prophylaxis, while those with over RSD 2000 spent, more often had continuous antibiotic therapy and associated therapy (Table 3).

Table 3. Financial aspects

\begin{tabular}{|c|c|c|c|c|c|}
\hline Funds & $\begin{array}{l}\text { Up to } 2000 \\
\text { dinars }\end{array}$ & $\begin{array}{l}\text { More than } \\
2000 \text { dinars }\end{array}$ & $\begin{array}{l}\text { Number of } \\
\text { patients }\end{array}$ & $x^{2}$ & $\mathbf{p}$ \\
\hline $\begin{array}{c}\text { Antibiotic prophylaxis } \\
\text { Continuous antibiotic } \\
\text { therapy and } \\
\text { associated therapy }\end{array}$ & $\begin{array}{l}26(72.2 \%) \\
10(27.8 \%)\end{array}$ & $0(0.0 \%)$ & $\begin{array}{l}26(59.1 \%) \\
18(40.9 \%)\end{array}$ & 14.123 & $<0.001$ \\
\hline Total & $36(100.0)$ & $8(100.0)$ & $44(100.0 \%)$ & & \\
\hline
\end{tabular}

\section{Discussion}

Postoperative infections are the main source of morbidity and mortality of surgical patients. Prophylactic use of antibiotics is indicated in neurosurgical operations where the risk of infection is greater than the risk of using antibiotics.

In neurosurgery, there is generally a low risk of infection compared to other surgical branches, only $3-4 \%$, due to surgical strategies, technological quality and progress $(10,11)$. Postoperative infections in neurosurgical patients can be dramatic, rapidly progressive forms of meningitis, epidural abscess, subdural empyema, brain abscess, ventriculitis, sepsis. Therefore, the prophylactic use of antibiotics has proven to be very useful (12-14).

However, some studies have shown that prophylactic use of antibiotics in neurosurgery is still controversial. In practice, there is a "struggle" between advances in aseptic procedures and the abuse of high-dose antibiotics of the broad spectrum as a "standard".

Our study showed that there was no statistically significant difference in wound infection depending on the use of antibiotic therapy $\left(\chi^{2}=\right.$ $1.076 ; p=0.583$ ) (Table 1 ). According to the results of numerous studies $(7,16)$, antibiotic prophylaxis leads to a reduction in the incidence of operative site infections. In contrast, this association in some other studies has not been confirmed (17, 18). Surgical infection increases the length of hospital stay (19). Prophylaxis has the potential to shorten hospital stay. There are several randomized studies that monitor the duration of hospital stay as a measure of outcome. They have shown that prevention of wound infection is associated with a faster return to normal activity after being discharged from the hospital (20).

A statistically significant difference was found during our study in the distribution of side effects depending on the use of antibiotic therapy $\left(\chi^{2}=\right.$ 15.634; $p=0.001$ ) (Table 2 ). A significantly higher number of patients who had antibiotic prophylaxis were without side effects, while patients with continuous antibiotic therapy more often had nausea 16 and vomiting, diarrhea and stomach pain. Antibiotics can cause disturbance of bacterial equilibrium in the intestines and allow the development of strains of bacteria that cause gases in the intestines and lead to inflammation. Sometimes antibiotics significantly destroy the normal intestinal flora, so the Clostridium difficile bacteria can accumulate and multiply in the intestines. It illuminates a very harmful substance in the human intestines and leads to a much more serious form of inflammation of the intestines called Pseudomembranous colitis. Diarrhea occurs during or shortly after taking antibiotics. Pseudomembranous colitis may occur practically after the administration of any antibiotic, or most commonly after the increase of Ampicillin, Clindamycin, Cephalosporin of the third generation and Fluoroquinolone (21). Exposure to systemic antibiotics leads to a disorder of normal colon flora and an increase in sensitivity to colonization and toxin production by Clostridium difficile and increases the risk of symptomatic Clostridium by 2 to 16 times (22). The unreasonable consumption of antimicrobial drugs is harmful to the health of patients, it causes possible side effects, toxic reactions and interactions with other drugs and leads to increased resistance of microorganisms to antibiotics (23). Therefore, we concluded that antibiotic prophylaxis should be applied in neurosurgery due to shorter time use of antibiotics, less overall dose, and less frequent appearance of serious complications due to shorter use of antibiotics. Several published guidelines (24-28) say that for all clean and most pure-contaminated procedures (the main problem of bacterial contamination of the skin), Cefazolin is the first choice medication due to its external action on a gram-positive coccus, which mainly causes skin contamination.

Very few prospective randomized studies of surgical prophylaxis included economic evaluation within the research. During our research, a significant statistical difference was found in financial resources depending on the use of antibiotic therapy $\left(\chi^{2}=14.123 ; p<0.001\right)$. Antibiotic therapy was used for prophylactic purposes and reduced the length of patients' stay in the hospital and did not cost more than RSD 2000, while the continuous use 
of antibiotics extended hospitalization and it costed financially more. For most surgeries, however, prophylaxis only reduces short-term morbidity. Surgical infection increases the length of stay in hospital (28). The additional length of stay depends on the type of surgery. Prophylaxis has the potential to shorten the stay in hospital. There is little direct evidence to suggest that, a few randomized studies of $(29,30)$ included the length of stay in hospital as a measure of outcome. This is the evidence that the prevention of wound infection is associated with a faster return to normal activity after being discharged from hospital.

Based on our research it is mandatory to provide optimum protection in the work by respecting the principle of asepsis, use prophylactic antibiotics after the patient's consent by giving a minimum dose adjusted for the risk of infection and the status of the patient, before the beginning of operation and 24 hours after surgery.

It should be noted that the prophylactic use of antibiotics is different from continuous antibiotic therapy; the use of high-dose broad-spectrum antibiotics has long been used as a standard but should be avoided.

\section{Conclusion}

Antibiotic prophylaxis should be applied in neurosurgery for the following reasons:

- shorter time of use of antibiotics,

- less overall dose of used antibiotics,

- rare occurrence of severe complications of long-term use of antibiotics (enteric infection with C. difficile, development of resistance),

- economic benefit comparing to continuous antibiotic therapy.

References

1. Hughes JM. Study of the efficacy of nosocomial infection control (SENIC Project). Chemotherapy 1988; 34 (6):553-61. [CrossRef] [PubMed]

2. Kirkland KB, Briggs JP, Trivette SV. The impact of surgical-site infections in the 1990s: attributable mortality, excess length of hospitalization, and extra costs. Infect Control Hosp Epidemiol 1999;20(11):725-30. [CrossRef] [PubMed]

3. Mangram AJ, Horan TC, Pearson ML. Guideline for prevention of surgical site infection. Infect Contr Hosp Epidemiol 1999;20(4):247-77. [CrossRef] [PubMed]

4. Culver DH, Horan TC, Gaynes RP, Martone WJ, Jarvis WR, Emori TG, et al. Surgical wound infection rates by wound class, operative procedure, and patient risk index. National Nosocomial Infections Surveillance System. Am J Med 1991;91:152S. [CrossRef] [PubMed]

5. Ilic M, Markovic Lj, Canovic D, Stefanovic S, Tepic K. Surgical site infections at the Surgery Clinic of the
Clinical Hospital Center in Kragujevac. Med Pregl 2004;57(7-8):369-73. [CrossRef] [PubMed]

6. Savitz MH, Malis L, Meyers BR. Prophylactic antibiotics in neurosurgery. Surg Neurol 1974;2:95-100. [PubMed]

7. Yeraght J, Feely M. Antibiotic prophylaxis in neurosurgery. J Neurosurgery 1984;60:724-6. [CrossRef] [PubMed]

8. Mini E, Nobili S, Periti P. Methicillin-resistant staphylococci in clean surgery. Is there a role for prophylaxis? Drugs 1997;6:39-52. [CrossRef] [PubMed]

9. Iacob G, Iacob S. Prophylactic antibiotherapy in Neurosurgery. Romanian Neurosurgery 2010; 3:323. [PubMed]

10. Health AJ. ASHP therapeutic guidelines on antimicrobial prophylaxis in surgery 1999;56:1839-88. [CrossRef] [PubMed]

11. Geraghty J, Freely M. Antibiotic prophylaxis in neurosurgery. Journal of Neurosurgery 1984;60:724-6. [CrossRef] [PubMed] 
12. Tenney J, Vlahov D, Salcman M, Ducker TB. Wide variation in risk of wound infection following clean neurosurgery. Journal of Neurosurgery 1985;62:2437. [CrossRef] [PubMed]

13. Young RF, Lawner PM. Perioperative antibiotic prophylaxis for prevention of postoperative neurosurgical infections. A randomized clinical trial. Journal of Neurosurgery 1987;66:701-5. [CrossRef] [PubMed]

14. Bullock R, Van Dellen J, Ketelbey W, Reinach SG. A double-blind placebo-controlled trial of perioperative prophylactic antibiotics for elective neurosurgery. Journal of Neurosurgery 1988;69:687-91. [CrossRef] [PubMed]

15. Leaper DJ, Melling AG. Antibiotic Prophylaxis in Nonshunt Clean Cranial Surgical Procedures 2013;96-101.

16. Phil J. Microbiol Infect Dis 2000;29(2):33-6.

17. Cabrera R, Gimenez R, Diez J, Lopez MJ, Banegas JR. Surgical site infection of 7301 traumatologic inpatients. Eur J Epidemiol 2004;19(2):163-9. [CrossRef] [PubMed]

18. Folk JW, Starr AJ, Early JS. Early wound complications of operative treatment of calcaneus fractures: analysis of 190 fractures. J Orthop Trauma 1999;13(5):36972. [CrossRef] [PubMed]

19. Maksimovic J. Faktori rizika za nastanak bolničkih infekcija operativnog mesta. [Magistarski rad]. (SRB); 2004.

20. Plowman R, Graves, N, Griffin, M. The socio-economic burden of hospital-acquired infection. Public Health Laboratory Service 2000. [CrossRef] [PubMed]

21. Davey PG, Duncan ID, Edward D, Scott AC. Costbenefit analysis of cephradine and mezlocillin prophylaxis for abdominal and vaginal hysterectomy. $\mathrm{Br}$ J Obstet Gynaecol 1988;95(11):1170-7. [CrossRef] [PubMed]

22. Kassam Z. Fecal microbiota transplantation for Clostridium difficile infection: Systematic review and metaanalysis. American Journal of Gastroenterology 2013; 108(4):500-8. [CrossRef] [PubMed]
23. Bagdasarian N. Diagnosis and treatment of Clostridium difficile in adults: A systematic review. JAMA 2015;313(4):398-408. [CrossRef] [PubMed]

24. Kirkland KB, Briggs JP, Trivette SL, Wilkinson WE, Sexton DJ. The Impact of Surgical-Site Infections in the 1990s: Attributable Mortality, Excess Length of Hospitalization, and Extra Costs. Infect Control Hosp Epidemiol 1999;20:725-30. [CrossRef] [PubMed]

25. Scottish Intercollegiate Guidelines Network. Antibiotic Prophylaxis in Surgery. A National Clinical Guideline 2008;35-6.

26. Bratzler DW, Houck PM, Surgical Infection Prevention Guidelines Writers Workgroup. Antimicrobial prophylaxis for surgery: an advisory statement from the National Surgical Infection Prevention Project. Clin Infect Dis 2004;38:1706-15. [CrossRef] [PubMed]

27. Therapeutic Guidelines Antibiotic Expert Group. Prophylaxis: surgical. U: Therapeutic Guidelines: Antibiotic v13. Melbourne: Therapeutic Guidelines Ltd., 2006. [PubMed]

28. Calise F, Capussotti L, Caterino S, Delitala A, Terrazzi $P$, Francucci $M$, et al. Perioperative antibiotic prophylaxis in adults. Outline of the principal recommendations. Minerva Anestesiol 2009;75(9):543-7, 548-52. [PubMed]

29. Plowman R, Graves, N, Griffin, M. The socio-economic burden of hospital-acquired infection. Public Health Laboratory Service 2000. [CrossRef] [PubMed]

30. Coello R, Glenister $H$, Fereres J, Bartlett C, Leigh D, Sedgwick J, et al. The cost of infection in surgical patients: a case-control study. J Hosp Infect 1993; 25(4):239-50. [CrossRef] [PubMed]

31. Lynch W, Malek M, Davey PG, Byrne DJ, Napier A. Costing wound infection in a Scottish hospital. Pharmacoeconomics 1992;2(2):163-70. [CrossRef] [PubMed] 


\title{
PREDNOSTI ANTIBIOTSKE PROFILAKSE U NEUROHIRURGIJI
}

\author{
Predrag Milošević ${ }^{1}$, Boban Jelenković1, Nebojša Miljković2, Goran Ivanov², \\ Miroslav Popović ${ }^{2}$
}

\author{
${ }^{1}$ Klinički centar Niš, Klinika za neurohirurgiju, Niš, Srbija \\ ${ }^{2}$ Klinički centar Niš, Klinika za anesteziju, Niš, Srbija \\ Kontakt: Predrag Milošević \\ Jovana Skerlića 10, 18000 Niš, Srbija \\ E-mail: pedja@doctor.com
}

Profilaktička upotreba antibiotika u neurohirurgiji podrazumeva upotrebu antibiotika u cilju sprečavanja infekcija rana i unutrašnjih operativnih struktura.

Istraživanje je sprovedeno na Klinici za neurohirurgiju u Nišu tokom 2018. godine i obuhvatilo je 44 bolesnika kojima je operisana hernija diska L4-L5 i L5-S1. Kod 26 bolesnika primenjena je antibiotska profilaksa. Kod preostalih 18 bolesnika nije sprovedena antibiotska profilaksa i oni su raspoređeni u kontrolnu grupu. Prosečno trajanje operacije bilo je 50 minuta. Antibiotik se koristi u jednoj dozi, cefalosporin prve generacije - cefazolin $1 \mathrm{~g}$ IV za bolesnike sa telesnom težinom manjom od $80 \mathrm{~kg} \mathrm{i} 2 \mathrm{~g}$ za bolesnike sa telesnom težinom većom od $80 \mathrm{~kg}$.

Primetili smo pojavu infekcija rana i unutrašnjih operativnih struktura, pojavu neželjenih efekata i posmatrali smo finansijske aspekte.

Cilj rada bio je pokazati da je antibiotska profilaksa povoljnija zbog kraće upotrebe antibiotika, manje nuspojava i ukupne finansijske koristi, u poređenju sa kontinuiranom antibiotskom terapijom.

Acta Medica Medianae 2020;59(2):14-19.

Ključne reči: antibiotska profilaksa, neurohirurgija, infekcije rana 